\title{
North Central Conference of The Renaissance Society
}

The annual meeting, on the topic "Renaissance Concepts of Community, Friendship, and Marriage," was held on April 20-22 at Carleton University in Ottawa. It was the best attended one in a number of years, with 73 delegates plus many visitors. The local committee, to whom the Conference is much indebted, was chaired by Don Beecher (English). Its other members were Clifford Brown (Art History), Massimo Ciavolella (Italian), Joseph Dallett (German), and Mark Phillips (History). Keynote addresses: James Beck (Columbia), "Leonardo and His Brothers"; George Hibbard (Waterloo), "Sequestration 'into Atlantic and Utopian Polities': Ideas and Realities of Community from More to Milton"; McAllister Johnson (Toronto), "Charles IX and His Court Discover the French Provinces, 1564-1566." Other papers (in order of presentation, simultaneous presentation having been necessary for each pair of the following): A.T. Wilson Hayes (Baruch College), "Gerrard Winstanley and the Utopian Family"; Pierre Hurtubise (St. Paul University, Ottawa), "A Family of Two Cities: The Florentine and Roman Branches of the Salviati"; John M.R. Margeson (Toronto), "Vows and Betrayals: The Two Gentlemen of Verona and The Two Noble Kinsmen"; Jonathan B. Riess (Cincinnati), "Leon Battista Alberti's Della Famiglia and the Civic Hero in Art"; Lindsay Mann (Carleton), "John Donne's Doctrine of Marriage"; Rita Belladonna (Western Ontario), "The Intellectual and His Environment: A Negative View Induced by Political Decay and Hidden Religious Dissent"; Randy S. Burge (Toronto), "The Wedding Masques of Ben Jonson"; Thaddeus Krukowski (Ottawa), "Community in Frycz-Modrzewski's Utopia"; A. D'Orsay Pearson (Akron), "Adolescent Marriage in Elizabethan Theory and Practice"; Daniel Lesnick (Hiram College), "The Popular Preacher and His Audience in Early Renaissance Italy"; Carroll Westfall (Illinois at Chicago Circle), "Papal and Princely Art in the Quattrocento Polity - Legitimacy, Magnificence, and Community"; Leanore Lieblein (McGill), "Narrative into Drama: Marriage and the Community in English Domestic Plays 1590-1610." The Elizabethan Consort under the leadership of Don Beecher gave a performance of remarkable virtuosity. An exhibit of Renaissance books on the conference topic was arranged by Joseph Dallett, Hilda Gifford, and Jeremy Palin.

After much thought the Board of the North Central Conference has decided on a change from the traditional date of our annual meetings. We hope that this will meet with the approval of the membership. Our impression is that the number of regional and other Spring conferences relating to the Renaissance offer an embarrass- 
ment of riches, and that for some sponsoring organizations, at least in Canada, the meeting dates cannot be significantly changed. The North Central Conference, on the other hand, is free to choose as it wishes. Our conclusion is that a date in late October is as attractive as, and less traffic-filled than, our traditional meeting-time in March or April. Accordingly we expect to hold our 1979 conference around October 21 , and to continue this practice in following years. Negotiations are far advanced for holding our 1979 session in Michigan, and for meeting in 1980 in southern Ontario and in 1981 in northern Ohio. We hope that members will keep these times and places in mind. A mailing should reach members and others in October of this year.

For 1978-79 Elizabeth Bieman of the University of Western Ontario will act as Co-ordinating Secretary while the present Secretary is abroad. She will be assisted by a committee composed of J.A.B. Somerset (Treasurer, continuing), P. Auksi, D.C. Kaula, E.N. Mellamphy, T. Sea, and honorary members W.K. Ferguson and J.G. Rowe, and advised by R. Belladonna, W.S.A. Dale, H.J. Johnson, and A. Santosuosso.

Present members of the Board of the North Central Conference are: Wallace K. Ferguson (Honorary Chairman, Western Ontario, retired), E.M. Beame (McMaster), E. Bieman (pro tem., Western Ontario), V.A. Doyno (Buffalo), P.J. Ford (Cleveland State), A.M. Fox (Queen's), E.R. Gregory (Toledo), G.R. Hibbard (Waterloo), A.K. Hieatt (Western Ontario), F.D. Hoeniger (Toronto), M.H.M. MacKinnon (Guelph), C.E. Rathé (York), J.A.B. Somerset (Western Ontario), C. Trinkaus (Michigan).

The October mailing will request further information about members' research and Renaissance courses in their institutions.

A. KENT HIEATT, Co-ordinating Secretary 